\title{
Selvmord som tema på Internett og i andre massemedier - ressurs eller risiko?
}

\author{
Ved Lars M ehlum
}

I løpet av de siste 10 årene har det skjedd store endringer i vår omgang med temaet selumord; både i den offentlige debatt, i massemedia og i dagliglivet. Den nye åpenheten omkring temaet har hatt mange positive virkninger. Det er lettere å arbeide åpent med forebyggende tiltak, og for alle dem som på en eller annen måte er berørt av selvmordsproblemet, er det blitt lettere å snakke åpent og be om hjelp. Men er all denne åpenheten og mediafokuseringen bare av det gode?"

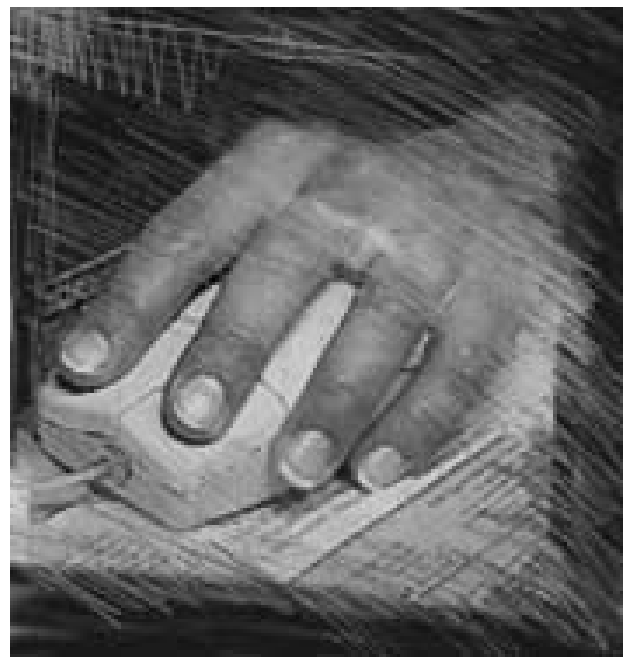

Ved bruk av det meget utbredte søkeverktøyet "A ItaV ista" gir et internettsøk på ordet "suicide" (engelsk og fransk for selvmord) ca 1 million treff (sept. 2000) Det vil si at ordet er brukt i ca en million internettdokumenter. Tilsvarende vil søk med det tyske "selbstmord" gi 30000 treff, det spansk/italienske "suicidio" 30000 treff, og det svenske "självmord" vil gi 6500 treff. D et norsk/danske "selvmord" vil tilsvarende gi 5300 treff.

M er raffinerte søkeprosedyrer ville sikkert gitt mer eksakt informasjon om innholdet på disse sidene. Her skal vi nøye oss med å konstatere at mange av disse nettstedene inneholder konstruktiv informasjon ment som et bidrag til bedre forståelse av selvmordsproblemet eller som en ressurs i det selvmordsforebyggende arbeidet. $M$ en forholdsvis mange nettsteder inneholder også informasjon som i større eller mindre grad kan øke faren for selvmord hos risikoutsatte in divider. Titler som "A practical guide to suicide", "Death net", "Selvmordsweb", "C hurch of Euthanasia", "Voluntary H uman Extinction M ovement" og "A It.suicide.holiday" taler vel sitt tydelig språk om hvilken innfallsvinkel noen av disse nettstedene har.

$\mathrm{H}$ vilke konsekvenser slik bruk av Internett kan få, ble svært tydelig i forbindelse med den tragiske hendelsen ved Preikestolen i Rogaland tidligere i år der to unge mennesker sammen tok sitt liv etter at de hadde inngått en selvmordspakt. Dette skjedde gjennom en diskusjonsgruppe på Internett viet spesielt til temaet selvmord. Denne hendelsen er grundig diskutert i Knutsens artikkel s. 24-25. Til tross for at temaet både er tragisk, oppsiktsvekkende og interessant, og derved påkaller massemediers og publikums interesse, ble omfanget av fokuseringen totalt sett omkring denne hendelsen og utformingen av oppslagene i visse media meget uheldig. Seksjon for selvmordsforskning og -forebygging (SSFF) ved U niversitetet i O slo har en kritisk holdning til en slik mediafokusering.

\section{Massemedia som forebyggingsressurs}

I utgangspunktet er norske massemediers interesse for og omgang med selvmord som aktuelt tema både positiv og konstruktiv. I samarbeid med eksperter på sel vmord og selvmordsforebygging har mediefolk bidratt til å skape større åpenhet om selvmord - et tema som tidligere var sterkt tabubelagt og fortiet. Vi er ikke i tvil om at denne åpenheten og interessen kan bidra til å endre negative og destruktive holdninger til selvmordsnære mennesker eller til etterlatte ved selvmord. Dermed kan flere mennesker få hjelp til å overvinne sine problemer og antallet selvmord kan reduseres. Denne utviklingen bør fortsette, og fagfolk som arbeider særskilt med selvmord vil fortsatt aktivt bidra til økt åpenhet. Ved SSFF legges det stor vekt på et godt samarbeid med massemedia. Eksempelvis ga medarbeiderne ved senteret i 1999 mer enn 50 intervjuer til massemedia og bidro dessuten til filmproduksjoner og informasjonskampanjer, bl.a. N RK Petres U ngdomskampanje 99, "D et finneshjelp mot nesten alt" (Reinholdt et al 2000). Vi har tro på at kombinasjonen av kreative mediefolk og erfarne eksperter på selvmord kan skape nye, spennende og konstruktive bidrag til selvmordsforebygging. Fagfolk innen forskning og forebygging bør bli enda flinkere til å formidle sin kunnskap til publikum og brukere. SSFF arbeider for å spre kunnskap blant annet gjennom dette tidsskriftet, Internett og andre media.

\section{Hva slags mediafokusering gir økt risiko?}

$M$ en dessverre er ikke all mediafokusering av det gode. Flere forskningsprosjekter har vist at sensasjonspreget omtale av konkrete tilfeller av unges selvmord, der selvmordssted og -metode beskrives og der det skildres detaljer omkring hendelsesforløpet, vil kunne føre til imiterende selvmordsatferd hos andre unge. Særlig godt kjent er pionerundersøkelsen utført av den amerikanske sosiologen Phillips, som allerede i 1974 var i stand til å demonstrere at sensasj on spreget avisomtale av selvmord økte risikoen for selvmord i avisens nedslagsområde (Phillips 1974). Liknende funn ble senere gjort når det gjaldt sensasjonspregete historier om sel vmord skildret i TV (Phillips \& Carstensen 1986). Fra nyere tid kjenner vi særlig Schmidtke og H äfners studie i Tyskland (1989). De påviste en klar $ø$ kning $\mathrm{i}$ antall togselvmord blant unge menn i Tyskland etter visning av en TVserie på seks episoder - en serie som fokuserte på en ung manns livsproblemer og i detalj skildret veien fram til han kastet seg foran toget og døde. Programserien hadde i utgangspunktet et selvmordsforebyggen de siktemål, men fikk altså helt motsatt effekt. A t uhel dig mediafokusering på selvmord kan lede til imiterende selvmord ble også vist i en østerriksk undersøkel se (Etzersdorfer et al. 1992). Da W ien på midten av 80-tallet opplevde en sterk økning i antall selvmord i byens tunnelbanesystem, ble det i samarbeid med den østerrikske foreningen for selvmordsforebygging utarbeidet strengere retningslinjer for medienes omtale av selvmord. Etter dette falt antallet tunnelbaneselvmord med hele $75 \%$. Endelig vil vi nevne erfaringene fra San Francisco og G olden $\mathrm{G}$ ate-broen, som er det enkeltsted i verden der flest mennesker ( som vi kjenner til) har tatt sitt eget liv. 




Hittil er det registrert over 1100 personer. $M$ en man regner med at det reelle tallet er langt høyere, fordi de som hopper fra broen, sjelden blir funnet i sjøen på grunn av de uvanlig sterke havstrømmene på stedet (). M otto, personlig meddelelse, 1997). Broen har lenge øvet en viss tiltrekningskraft på alle som går med selvmordstanker, men situasjonen kom helt ut av kontroll for en del år tilbake da store avisoppslag ledsaget hvert nye selvmordstilfelle på broen. Da massemedia etter oppfordring fra det lokale fagmiljøet sluttet å omtale konkrete nye tilfeller av selvmord på broen, falt også antall broselvmord raskt.

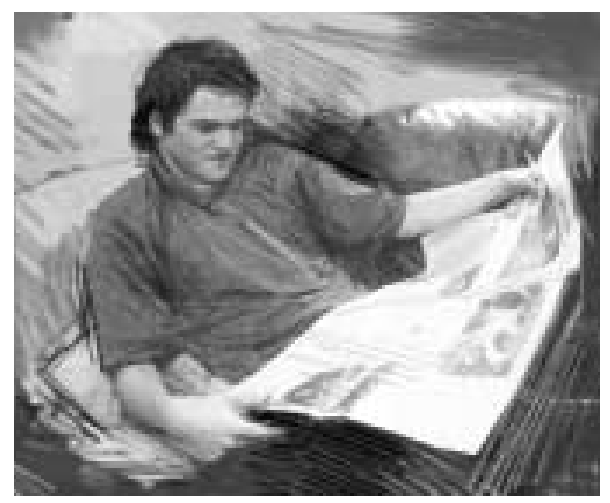

Ungdom er

mest utsatt for påvirkning

Det er viktig å merke seg at det særlig er ungdom som er påvirkelig for slik uheldig omtale av selvmord i massemediene. Det kan dreie seg om både fiktive skildringer og reportasjer fra reelle hendel ser; det er gitt eksempler på begge deler ovenfor. Faktiske epidemier av selvmord blant unge kan oppstå, og vi har årlige eksempler i vårt eget land på at det forekommer. Et relativt nytt utviklingstrekk i det samme problemkomplekset er formidling av "smitte" eller negativ påvirkning gjennom Internett. A v ulike årsaker søker enkelte ( særlig unge mennesker) sammen på nettsteder viet selvmordsdiskusjoner. Felles for disse stedene er at sel vmord ofte fremholdes som en løsning, og det leveres både argumentasjon og beskrivelser av "gode" metoder for utførelse av selvmordshandlingen. V i ser også eksempler på at det inngås avtaler om sel vmord gjennom slike nettsteder. A t det finnes ungdommer som er mottakelige og påvirkelige for den slags budskap, er jo vist med all mulig tydelighet i den aktuelle saken fra Preikestolen, jfr. V G s oppslag 23.02.00 hvor det stod: "M annen i 20-årene sendte 9. februar ut en engelsk-språklig melding på dette nettstedet, hvor han gikk rett på sak - og etterlyste en person som ville begå selvmord sammen med ham. $\mathrm{H}$ an kunne gjerne finansiere reisen hvis det sto på penger. $\mathrm{H}$ an fikk en rekke svar på nettet ....". Blant annet fikk han svar fra den norske jenta som senere meldte seg for politiet, og fra den østerrikske 17-åringen som han gjorde selvmord sammen med.

\section{Forebyggende tiltak}

En umiddelbar reaksjon på slike hendelser ville kanskje være å kreve forbud mot slik bruk av Internett. M en nettsteder som dette kan neppe stanses. Ei heller kan foreldre eller andre effektivt kontrollere hva unge mennesker søker opp gjennom Internett. Derimot kan tradisjonelle massemedia unnlate å informere om disse nettstedenes eksistens, og derved unngå å bidra til å rekruttere nye brukere til slike destruktive nettsteder. I pressens egen "V ær varsom-plakat" (1994) pkt 4.9 heter det (fortsatt): "Selvmord eller selvmordsforsøk skal som hovedregel ikke omtales". H er gjelder det, slik vi forstår det, ikke selvmord som tema i seg selv, men omtale av konkrete tilfeller av selvmord. Begrunnelsen for dette behovet for varsomhet er gitt ovenfor. I visse tilfeller vil det likevel være riktig å informere om konkrete tilfeller av selvmord. Da bør følgen de forholdsregler tas:

1. U nngå sensasj onspregete oppslag. Rapporter ikke dramatiske detaljer. U t fra hensynet til å unngå smitteeffekter bør oppslag om sel vmord ikke få fremtredende plass.

2. M assemedia bør ikke omtale hvordan det konkrete selvmordet er utført eller detaljer om hvor det er utført.

3. Selvmord bør ikke beskrives som en løsning på problemer.

4. A rsakene til et selvmord bør ikke presenteres overforenklet. Som regel er det et helt sett av prosesser som ligger bak et selvmord. O verforenklende omtale av typen "Foreldre oftest skyld i barns selvmord", er krenkende.

5. U nngå å forherlige selvmordet eller den avdøde. I stedet bør man eventuelt fokusere på de store problemene et slik dødsfall skaper for de etterlatte.
$\mathrm{H}$ vilke andre retningslinjer som gjelder ved medieomtale av konkrete selvmord og hvordan vi kan motvirke at selvmordsepidemier bryter ut, er beskrevet tidligere i Suicidologi (Y stgaard 1997) og andre steder (G røholt 1999). Her er det altså viktig at massemedia respekterer visse forholdsregler. Vi innser at disse forholdsreglene kan oppleves innskrenkende på fri utøvel se av pressens virksomhet, ja som et angrep på pressefriheten. Dette er ikke hensikten. M en alle massemedier må ta inn over seg de påviste sammenhenger mellom uheldig omtale av selvmord i media og økt risiko for imiterende selvmordshandlinger blant risikoutsatte individer. A lle ansvarlige mediefolk bør bidra til å unngå en utglidning på dette området. For alle oss som arbeider med forskning, forebyggingstiltak eller klinisk virksomhet, er det likeledes et ansvar å være aktive i formidlingsarbeidet og tenke kreativt om samarbeidet med massemediene.

\section{Referanser}

Etzersdorfer E, Sonneck G, N agel-Kuess S. $\mathrm{N}$ ewspaper reports and suicide. $\mathrm{N}$ ew England journal of medicine 1992; 327: 502 - 503.

Grøholt, B. Selvmord, smitteeffekt og massemedia. I M ehlum L (red). Tilbake til livet: selvmordsforebygging i teori og praksis. Kristiansand: Høyskoleforlaget, 1999: 303-17

Phillips DP. T he influence of suggestion on suicide: Substantive and theoretical implication of the Werther effect. A merican sosiological review 1974; 39: 240 - 254.

Phillips DP, C arstensen LL. C lustering of teenage suicide after television news stories about suicide. $\mathrm{N}$ ew England journal of medicine 1986: 685-689.

Reinholdt N P, M ehlum L, Ystgaard M . "D et finnes hjelp mot nesten alt". Evaluering av Petrekampanjen 1999. Suicidologi 2000; 1: 19-21.

Schmidtke A, H äfner $H$. Public attitudes towards an effect and mass media on suicide and deliberate selfharm. I RFW Diekstra. Suicide and its prevention. The role of attitude and imitation. Leiden: Brill, 1989: 311-330.

Ystgaard, M. Selvmord blant ungdom - er det smittsomt? $N$ ytt i suicidologi 1997; 2 (3): 12-14.

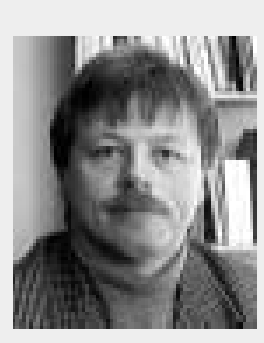

Lars M ehlum er psykiater og professor i suicidologi ved U niv. i O slo. Han er leder for SSFF og er bredt engasjert i en rekke forsknings- og forebyggingsprosjekter. $\mathrm{H}$ an har publisert flere lærebøker, samt en rekke vitenskapelige artikler. 